The value of such an exegesis remains historical rather than scientific. Les plis cachetes and other furtive, variable memoranda should never determine precedence in scientific discovery against another's public avowal of his views and his willingness openly to abide the question. Those who plot priority gain little. "We own they're prudent, but who owns they're good?" It is sad to be so often reminded by this erudite and educative discussion that Lavoisier's reputation (" $j$ 'étois avide de gloire") might have been still more splendid had it given him less concern. Here, too, he had something to learn from Dr. Black.

ANDREW KENT

\section{HISTORICAL ASPECTS OF CHEMISTRY}

\section{Chymia}

Annual Studies in the History of Chemistry, Vol. 7. Edited by Henry M. Leicester. (Edgar F. Smith Memorial Collection: University of Pennsylvania. University of Pennsylvania and Division of History of Chemistry, American Chemical Society.) Pp. 152. (Philadelphia : University of Pennsylvania Press; London: Oxford University Press, 1961.) 40s. net.

$\mathrm{T}$ HE regular appearanee of this annual publication solely devoted to the history of chemistry is very commendable and must undoubtedly be of considerable assistance to students in that field. In reviews of earlier volumes attention was directed to the high standard of the articles and their interest to chemists generally, and these features are well maintained in the present issue. It contains an essay on biochemical concepts among tho ancient Greeks by H. M. Leicester; three articles by M. Levey on Indian alchemy, the Muslim developments of the atomic theory, and an aspect of Arabic chemical technology; a continuation by R. Rappaport of her article on Ruelle in the last volume; "a curious Lavoisior episode" related by $\mathbf{H}$. Guerlac; some Russian material on Berzelius assembled by Y. Y. Solov'ov; an account of American editions of Davy's book on agricultural chemistry by W. H. Miles; and a survey of early studies of the influence of time on chemical and physical changes by E. Farber. Levey thinks previous publications on Muslim alchemy tend to underestimate the technical achievements, and he translates part of a manuscript by Ibn Badis (A.D. 1007-61) giving recipes for various kinds of inks, including one which writes black on white and white on black.

Solov'ev's article on Berzelius has some interesting material on G. I. Hess, one of the founders of thermochemistry who spent a short time in Stockholm with Berzelius, on Fritsche, who worked with platinum metals and rediscovered and named aniline, and Klaus, who discovered ruthenium. Berzelius corresponded extensively with contemporary chemists and the exchange of letters between him and the Russian chemists presented here is of interest. Farber's essay on the influence of time in chemical and physical changes assembles some little-known material, for example, the publications of Proust (1810-14) on the influence of composition on the rate of burning of gunpowder, and Liebig's (1849) on the acceleration of esterification by mineral acids.

This volume should be of interest to chemists, and some of the articles have a wider appeal. The printing and binding are very good. J. R. Partington

\section{METHODS IN CHEMICAL ANALYSIS}

\section{Chemical Analysis}

The Working Tools. Edited by C. R. N. Strouts, H. N. Wilson and R. T. Parry-Jones, with the assistance of J. H. Gilfillan. Vol. 1: Pp. xvi $+467+4$ plates. Vol. 2: Pp. $x+479+13$ plates. Vol. 3: Pp. xii $+273+1$ plate. Revised edition of "Analytical Chemistry" first published in two volumes in 1955. (Oxford: Clarendon Press; London: Oxford University Press, 1962.) 147s. net the set of three volumes.

Treatise on Analytical Chemistry

Edited by I. M. Kolthoff and Philip J. Elving. With the assistance of Ernest B. Sandell. Part 2: Analytical Chemistry of the Elements. Vol. 2: Pp. xx +471. Vol. 9: Pp. xvi 491 . (New York and London: Interscience Publishers, a Division of John Wiley and Sons, Inc., 1962.) 135s, each volume.

$M$ OST cenologists would agree with the trite saying: "It is not the label on the bottle that matters, it is the quality of the wine which counts".

(1) This remark could equally well apply to this recent, revised, three-volume edition of that wellknown vade-mecum on chemical analysis which was first published seven years ago by the Analytical Chemists' Committee of Imperial Chemical Industries, Ltd. The title of the new edition has, indeed, been slightly changed, but the excellence of the contents will undoubtedly retain the approbation of those perceptive analysts who sampled the earlier vintage.

It is one of the tribulations of continued scientific progress that many of our analytical "working tools" can become obsolescent or greatly modified with the passage of a very few years. Periodic revision of authoritative scientific publications is thus an accepted necessity, and no discipline has grown or expanded so rapidly as that complex field which includes both chemical and instrumental analysis.

Volume 1 of the new edition deals lucidly with the application of statistical methods, accuracy, sampling procedures, measurement of physical constants, apparatus and its calibration, ete., the textual notes being embellished by a wealth of informative practical laboratory detail. Paper, columnar, gas-solid and gas-liquid chromatographic techniques are given a detailed description in this volume, which also includes a new chapter on vacuum fusion and extraction methods for the determination of gases in metals. Isotope dilution methods, titrimetry in non-aqueous solvents, and microscopy receive brief mention.

Approximately one-third of Volume 2 is devoted to the quantitative applications of conductimetric and electrometric methods, including the simpler Heyrovsky and cathode-ray polarographic techniques. Coulometric methods are also described and, because of the exactness of such determinations, they are obviously worthy of much attention by the up-to-date analyst.

The volume concludes with lucid theoretical and practical sections on visual colorimetry, fluorimetry and absorptiometry. The chapters on ultra-violet absorption, infra-red spectroscopv, flame photometry, X-ray diffraction and on the popular $\mathrm{X}$-ray fluorescence analysis method are ably written and provide a wealth of instruction for the tiro and a 